American Journal of Qualitative Research

June 2018, Vol.2 No. 1, pp. 97-117

(C) 2018 AJQR. http://www.ajqr.org/
AMERICAN

JOURNAL OF QUAUTATIVE

RESEARCH

ISSN : 2576-2141

\title{
Gangs and environment: A comparative analysis of prison and street gangs
}

\author{
Jennifer M. Ortiz \\ Indiana University Southeast, USA
}

\begin{abstract}
One misconception in gang research is the assumption that prison gangs and street gangs are organizationally and ideologically synonymous. Although in the minority, some researchers suggest that prison gangs are qualitatively and quantitatively different from other gangs (Fleisher \& Decker, 2001). Utilizing 30 in-depth semi-structured interviews with formerly incarcerated gang members in the New England area, this article assesses the effect of environment on the organizational structure, ideologies, and practices of prison and street gangs. The analysis presents a comparative model of prison and street gangs that highlights differences across major aspects of each type of organization, including membership, leadership, organizational operations, and relationships with authority figures. These findings suggest a need for researchers to explore prison and street gangs as distinct entities each affected by their respective environments. Policy suggestions and directions for future research are discussed.
\end{abstract}

KEYWORDS: prison gangs, street gangs, gangs, subculture, environment

\section{Introduction}

A vast body of literature exists on street gangs that examines a wide array of topics including the emergence, membership, structure, and culture of street gangs (Brotherton \& Barrios, 2004). There is no comparable body of literature for prison gangs. Further, there is minimal research that calls into question the assumption that street gangs and prison gangs are synonymous entities. Researchers have only a "rudimentary knowledge of prison gangs as social groups operating inside prisons" (Fleisher \& Decker, 2001, p.2). Nearly all existing gang literature focuses on street gangs while ignoring prison gangs and the potential impact of environment and incarceration on gangs (Irwin, 1980; see Jacobs, 1977 for an exception, Michou at el., 2016) Anthropological research suggests that space and environment are essential to the understanding of cultural formation (Kaya \& Aydin, 2016; Damgaci \& Aydin, 2013; Low \& Lawrence-Zuniga, 2003). Existing gang literature fails to account for the potential effect of environment on gang characteristics. This 
present study attempts to address this shortcoming in the literature by assessing prison gangs and street gangs as two human collectives each affected by their respective environments.

Sykes' (1958) seminal work on prisons was one of the first to suggest that prison constitutes a society separate and different from 'free-society'. Existing research on prisons illustrates stark contrasts between captive and free societies. Total institutions, such as prisons, represent primitive societies because they cease to evolve in many ways as a result of being physically segregated from 'free' society (Rhodes, 2001; Suliman et al., 2016; Wang, 2015). Prison is also distinct from free society because residents' day-to-day interactions are strictly regulated. Within total institutions, such as prison, all aspects of life occur within the same location with the same individuals, same authority, and the same mundane daily routine (Deniz \& Ersoy, 2016; Goffman, 1961). As Beaumont and Tocqueville (1833) stated in their report on American penal institutions "while society in the United States gives the example of the most extended liberty, the prisons of the same country offer the spectacle of the most complete despotism" (p.47). Furthermore, within prisons there is a lack of privacy. Both staff and fellow inmates closely monitor interactions between individuals, creating an "omni-optical" society (Cohen and Taylor, 1972), and resulting in a lack of trust within captive societies that limits inmate ability to form meaningful relationships. Conversely, in 'free' society individuals enjoy privacy within their homes, are able to assess individuals in various environments, and are able to form trusting relationships. There are factors that appear in both the captive and free society including surveillance, education, family units, and religion. However, these factors may operate differently across the societies. The operation of these factors within a given environment may affect the culture of that society and the emergence of gangs within the society.

Nearly all existing gang literature focuses on street gangs while largely ignoring prison gangs and failing to test whether existing street gang literature is applicable to prison gangs (Gaes, et. al, 2001). This is in spite of research that suggests gangs vary across free societies (Rodgers \& Jensen, 2008) and even within a single neighborhood (Diego Vigil, 2002). If gangs differ across societies than it is logical to suggest that gangs in prison differ from gangs in free society.

Researchers have theorized that there are differences between prison gangs and street gangs. Gaes et al. (2001) posited that gang membership in prisons is less fluid compared to street gang membership. A qualitative analysis of prison gang leadership found that qualities for gang leadership differed in prison compared to the free world (Fortune, 2003). Brotherton and Barrios' (2011) ethnographic study of Dominican deportees reveals differences between prison-only gangs and gangs that exist both at the prison and street level. Decker, Bynum, and Weisel's (1998) work suggests that prison gangs more closely resemble organized crime structures compared to street gangs. Some studies suggest that prison gangs are so diverse that there are differences between the same gang in different states and even within different facilities within one state (Parenti, 1999). Ethnographic research on the Almighty Latin King and Queen Nation, an organization that exists both in the free world and within the correctional system, revealed differing goals between the street organization and the prison gang version of this association (Brotherton and Barrios, 2004). Some studies suggest that prison gangs are so diverse that there are differences between the same gang in different states (Parenti, 1999). Skarbek (2014) found that prison gangs emerged to combat institutional governance issues, indicating that prison gangs emerge for different reasons than street gangs. In spite of these existing studies, comparative studies of prison and street gangs are almost non-existent in the existing gang literature. 
The present study is significant to the existing gang literature because it speaks to a gap in the empirical and theoretical literature on the prison/street gang comparison. While most prison gang studies focus on the West Coast of the United States, this study provides a glimpse of prison gangs on the East Coast. By analyzing the narratives of individuals who directly experienced membership in both organization types, this study provides gang researchers with an alternative perspective on prison gangs and a starting point for understanding the similarities and differences between prison and street gangs. These new data reveal the effect of the environment on gang membership, leadership structure, and organizational operations. In addition, the study sheds light on how environment affects relationships between gangs and criminal justice officials. Collectively, these findings reveal that environment has an effect on gangs. These findings have implications for correctional classification policies.

\section{Methodology}

Methodologically this study consisted of an exploratory qualitative inquiry involving 30 in-depth semi-structured interviews with formerly incarcerated gang members. The purpose of this qualitative inquiry was to address the central research question: Does environment affect how individuals experience gang membership in prison compared to their street experiences? If so, how?

\section{Data Collection}

This study utilized a purposeful respondent-driven sampling strategy. While purposeful sampling suffers from the shortcoming of generating a non-representative sample, this sampling method is ideal for hard to reach populations (Faugier \& Sargeant, 1997) such as formerly incarcerated gang members. The characteristics of interest to this study were individuals who were 18 years of age and experienced gang membership both in the free world and in an adult correctional facility. An essential aspect of data collection was the use of gatekeepers (Seidman, 2013) who facilitated ease of access to the sample. Gatekeepers in this study consisted of current and former gang members who introduced the researcher to the initial sample. The researcher had access to twelve (12) individuals who fit the criterion for this study via personal networks and affiliations with organizations that provide services to the formerly incarcerated population. The initial group of respondents served as intermediates, recruiters, and references for the remaining sample. Upon completion of each interview, the researcher provided each participant with business cards and asked each respondent to refer potential participants to the study. This study allowed participants to self-identify as gang members. "The self-nomination technique is a particularly robust measure of gang membership capable of distinguishing gang [members] from nongang youth." (Esbensen et al, 2001, p. 95). Furthermore, self-identification is used both by researchers and prison officials when studying prison gangs (Gaes et al, 2001).

The sample had an average age of 29.48 and served incarcerative sentences ranging from four months to fifteen years. These individuals experienced incarceration in different states within the New England area and across multiple jurisdictional levels including federal-, state-, and county-level facilities (see Table 1). Eight sample members (26.6\%) experienced incarceration in multiple jurisdictions.

Interviews ranged in length from twenty minutes to two hours, with an average length of 61 minutes. The initial interview instrument contained questions covering a wide range of topics. 
Interview questions ranged from a discussion of the interviewee's experiences to general questions about prison and street gang structure, membership, roles, and norms. The researcher also posed general questions regarding cultures in each society, rationales behind joining gangs, and the roles of gangs in each society. Several interview questions allowed the interviewee tp express his opinions regarding similarities and differences across gang types and environments. Interviews concluded by asking each interviewee to reflect on their overall experiences with gangs.

\section{Data Analysis}

Recorded interviews were manually transcribed verbatim. Although the data analysis occurred manually, the researcher utilized the Atlas Ti qualitative data analysis software to manage the data. Atlas Ti allowed the researcher to link files related to each interview and to quickly search for similar codes and themes across interviews. Following the manual transcription of each interview, the researcher reviewed the transcript and utilized the first reading to developed cover page memos. Memoing is essential to qualitative data analysis because it allows for reflexivity (Erikkson, Hentonnen, \& Merilainen, 2012).

Table 1.

Demographics of the Participants

\begin{tabular}{|c|c|c|c|c|}
\hline \multicolumn{2}{|c|}{$\begin{array}{l}\text { Respondent } \\
\text { (Pseudonyms) }\end{array}$} & \multicolumn{3}{|c|}{ Incarceration Incarcerations } \\
\hline Clarence & United Blood Nation & 31 & 9 years & New Jersey \\
\hline Tyrone & United Blood Nation & 28 & 8 years & New Jersey and New York \\
\hline Luis & United Blood Nation & 24 & 4 months & New Jersey \\
\hline George & United Blood Nation & $\begin{array}{l}--- \\
1\end{array}$ & $\begin{array}{l}---------- \\
3\end{array}$ & New Jersey \\
\hline Chris & United Blood Nation & 26 & 8 years & New Jersey and Federal \\
\hline Reggie & United Blood Nation & 32 & 13 years & New Jersey and New York \\
\hline Richard & United Blood Nation & 22 & ---------3 & New Jersey \\
\hline Maurice & United Blood Nation & 24 & $31 / 2$ years & New Jersey \\
\hline Tom & United Blood Nation & 23 & $4 \frac{1}{2}$ years & New York and Federal \\
\hline David & $\begin{array}{c}\text { Almighty Latin King and Queen } \\
\text { Nation }\end{array}$ & 33 & 6 years & New York and Pennsylvania \\
\hline Antonio & Asociación Ñeta & 31 & 5 years & New York and Puerto Rico \\
\hline Ray & Asociación Ñeta & 28 & 3 years & Puerto Rico and Pennsylvania \\
\hline Morgan & $\begin{array}{l}\text { Almighty Latin King and Queen } \\
\text { Nation }\end{array}$ & 36 & 7 years & New York \\
\hline Anthony & $\begin{array}{l}\text { Almighty Latin King and Queen } \\
\text { Nation }\end{array}$ & 27 & $21 / 2$ years & New York \\
\hline Raul & $\begin{array}{l}\text { Almighty Latin King and Queen } \\
\text { Nation }\end{array}$ & 57 & 15 years & New York \\
\hline Frank & United Blood Nation & 40 & 2 years & New York \\
\hline Tony & $\begin{array}{c}\text { Almighty Latin King and Queen } \\
\text { Nation }\end{array}$ & 26 & 3 years & New York \\
\hline
\end{tabular}

\footnotetext{
${ }^{1}$ Respondent did not disclose this information.
} 


\begin{tabular}{|c|c|c|c|c|}
\hline Mike & United Blood Nation & 34 & 6 years & New York \\
\hline Edward & United Blood Nation & 34 & 15 years & New York \\
\hline Ricky & $\begin{array}{l}\text { Almighty Latin King and Queen } \\
\text { Nation }\end{array}$ & 23 & 1 year & New York \\
\hline Johnny & $\begin{array}{l}\text { Almighty Latin King and Queen } \\
\text { Nation }\end{array}$ & 33 & 12 years & $\begin{array}{c}\text { New York, Pennsylvania, and Puerto } \\
\text { Rico }\end{array}$ \\
\hline Hector & $\begin{array}{c}\text { Almighty Latin King and Queen } \\
\text { Nation }\end{array}$ & 30 & 4 years & New York \\
\hline Darryl & $\begin{array}{l}\text { Almighty Latin King and Queen } \\
\text { Nation }\end{array}$ & 21 & 3 years & New York \\
\hline Scott & $\begin{array}{c}\text { Almighty Latin King and Queen } \\
\text { Nation }\end{array}$ & 25 & $51 / 2$ years & New York \\
\hline Dominic & United Blood Nation & 19 & 1 year & New York \\
\hline Dante & Crips & 34 & 9 years & New York \\
\hline Jason & United Blood Nation & 29 & $41 / 2$ years & New York \\
\hline Brandon & United Blood Nation & 39 & $91 / 2$ years & New York \\
\hline Kendrick & United Blood Nation & 21 & 1 year & New York \\
\hline Felix & $\begin{array}{l}\text { Almighty Latin King and Queen } \\
\text { Nation }\end{array}$ & 25 & 2 years & New York \\
\hline
\end{tabular}

The initial data analysis phase utilized the listening guide strategy (Maxwell \& Miller, 2007), which entails reading interview transcriptions multiple times and discerning different information during each reading. The initial reading forms a detailed summary of the interview while subsequent readings address the study's research questions. The second phase of data analysis, data reduction, involved the use of coding and thematic analysis. Thematic analysis is the most common form of qualitative data analysis (Guest, 2012) and begins with the creation of codes. Coding is a method of data reduction that involves the development of words or phrases "that symbolically assign a summative... attribute for a portion of language-based or visual data" (Saldana, 2012, p. 2). The researcher utilized two types of codes: descriptive and In-Vivo. Descriptive codes involve summarizing the primary topic of a line or passage in the transcript (Saldana, 2012). In-Vivo coding involves creating codes "taken directly from what the participant himself says" (Saldana, 2012, p. 3). Upon completion of coding, the researcher utilized thematic analysis to locate and develop common themes across the data. Thematic analysis involves locating similar codes or trends in the data and collapsing these codes into large themes or findings (Bernard \& Ryan, 2009). There are fourteen different thematic methods of data analysis described by Bernard \& Ryan (2009). The researcher used three of the fourteen methods including similarities and differences, indigenous typologies and categories, and metaphors and analogies (Bernard and Ryan, 2009). These methods involve comparing different data. In this study, the researcher compared similarities and differences across interviews and between gang types (i.e. prison and street gangs).

\section{Limitations}

Although this study did not aim for generalizability, there are limitations to the data. A primary limitation is generalizability outside of the New England area of the United States. The interviewees primarily experienced incarceration in New York, New Jersey, and Pennsylvania. It is probable that the findings do not extend beyond this area of the country. A second limitation to 
the findings centers on organization. Due to the respondent drive sampling method, most of the respondents (27 out of 30) were members of two gangs, which may limit the transferability of findings. However, one should note that the two gangs differ from one another in terms of ethnic makeup, location of origin, and primary location of incarceration.

\section{Results}

The data revealed differences across prison and street gangs (see Table 2). Gang membership and leadership structures in prison are rigid and not susceptible to the changes common amongst street gangs. Environments affect how gangs manage conflict. Violence and crime in the street gang is chaotic while prison gang violence and crime is controlled by gang leaders due to a mutual need for violence reduction within correctional facilities. Lastly, while street gangs experience an antagonistic relationship with law enforcement because of formal policies such as stop and frisk and informal policies such as harassment of identified gang members, prison gangs have a complicated relationship with correctional staff that is determined by the type of correctional officer present in a facility.

Table 2.

Prison and Street Gang Comparison

\begin{tabular}{c|cc} 
& Prison Gang & Street Gang \\
\hline Membership & Rigid; must be earned & Fluid; Can be purchased \\
Leadership & Hierarchical and Rigid & Hierarchical but Fluid \\
Initiation & Violent, Criminal, or "Blessed" & Violent, Criminal, or "Blessed" \\
Control over Members & Strict Control Exerted & Little Control Exerted \\
Conflict Management & Controlled by Leadership; & Chaotic, uncontrolled \\
& Limited & \\
Relationship with & Complicated & Antagonistic \\
Criminal Justice \\
Representative
\end{tabular}

\section{Membership}

The data revealed similarities and differences between memberships in both organizations. Initiation into both organizational types consists of similar methods including physical violence, committing crimes or 'putting in work', and being 'blessed'2 in by a higher ranking member. Clarence stated that the method of initiation was chosen by the gang not the individual who wanted to join the organization.

\footnotetext{
2 "Blessed in" refers to an initiation process that does not require the individual to prove their worth because they are known to a high ranking member.
} 
Somebody joining a gang, you go to a gang. You tell them you want to be in. And they pick a method on how you're going to get in. [It's the] same way in jail, you need to get beat up, jumped in, you are blessed in, or you can go put in work.

Tyrone described two different initiation processes, 'tap out' and 'five rounds', that both required the use of physical violence.

A tapout [involves] you standing in [a] group of five [members] and you fighting until you felt you couldn't take it anymore and tap out. Five rounds would be you standing with that group of five and the round is stopped every time you hit the ground. I got five rounds. You have to get up in order to start the next round. But every time you hit the ground your round will be over... it was a rule [that] you can't put your feet on blood. That was like the ultimate disrespect. So even if you hit the ground, no one will put their feet on you. (Tyrone)

Although respondents acknowledged similarities with regard to initiation processes, not all street membership was recognized in prison. This is particularly true of the "blessing in" process. David, a Latin King, was blessed into his organization, however, upon entering prison David's membership was not recognized by the gang, which asked David to earn his membership into the prison organization by committing a criminal act. When David refused, he fell victim to his "own" organization.

[In prison] I wasn't a real King because according to what they told me, the guy who crowned me was not a Corona ${ }^{3}$. I don't know, he could have been, could not, so I don't really know if he was or he wasn't. I never saw the guy again. According to them, he wasn't a Corona so in order for me to be part of the Latin Kings I was given a kite. A kite is a note you get in prison. You get this little note and it tells you what to do. You read it, tear it up, flush it, burn it, whatever you want so there's no evidence. I read it and choose not to. I choose not to do it. So there were consequences and repercussions. I was beaten by the Kings, I was raped by the Kings and then I was stripped by the Kings.

Unwillingness to recognize street gang membership is especially prevalent amongst those individuals who serve incarcerative sentences in jurisdictions other than the one where they resided. Tom, a resident of New Jersey, explained the difficulty he experienced upon entering a New York State correctional facility

I'm from Jersey and they're from New York, we got two different respect levels. They didn't know who I was. They didn't believe I had [rank]. They told me I had to prove myself but... I don't follow nobody, I don't follow nobody rules... So I ended up fighting [people] who are supposedly my brothers.

Lack of membership recognition and having one's membership status revoked by the prison gang is further supported by Ray's story of entering a prison in Puerto Rico. He stated, "I got to PR and

\footnotetext{
${ }^{3}$ High ranking member with the ability to initiation someone into the organization.
} 
[the Netas] stripped me, told me that the [beads] were bullshit that I better not come in here with that Nuyorican ${ }^{4}$ bullshit".

Membership in prison and street gangs also differs on level of fluidity. Within prisons, individuals are unable to willingly leave the organization. Tyrone described how the prison gang would mete out violent punishments for members who violated rules. Once the individual recovered from the 'discipline' he was expected to return to the organization.

No matter what the discipline is. [Whether its] you and your bunkie in the yard with three other people or you in the cage and four people stabbing you. It's the ultimate discipline for you. You did something that you aren't supposed to do. Now you're paying for it. So how do you feel now that they stabbed you up? You don't want to be right there with them. But when you get out of ICU, you bring your ass back to the unit... You're gonna come back. You ain't gonna feel comfortable but you gonna come back.

Gang leaders discipline their members for a variety of rule violations including harming rival gang members without authorization (Trammell, 2009). Respondents also explained how prison gang members circumvented anyone's attempts to renounce their membership. Clarence discussed a mechanism used to ensure members who attempted to renounce their membership would be reclassified as a gang member.

You sign the paper [renouncing your membership] and the minute you reach general population, guess what I'm gonna do? I'm gonna spread the word to everybody that you said you're not gangbanging anymore. And if I really want you, I'll send you a letter... saying you're the new double $\mathrm{OG}^{5}$ of the [gang]. You just got to general population [and] this is my way of getting you back here [in the gang unit]. I'll send you a letter and they'll ship you back to Gang Unit. Guess who be waiting? Me and about a hundred other people... This is where the violence happens... it's like that everywhere.

While respondents acknowledged that they were also unable to ever fully renounce their street gang membership, they were able to reduce their gang activity either for parole or family reasons without fear of repercussions. These findings support Gaes et al's (2001) finding that prison gang membership is less fluid than street gang membership.

\section{Leadership}

Leadership and rank also differ between the street and prison gangs. Respondents acknowledge that it is easier to acquire a leadership role on the streets compared to within prisons. Within prisons acquiring a position of power involves spending an extended period of time within the organization.

You see in prison, you have to really deserve [rank]. It takes 10 years for you to be qualified to become a legit leader. You see, you've got people running around the street who's been banging for four years that's almost got to [the rank of] OG. He comes into prison and he ain't got shit.

\footnotetext{
${ }^{4}$ Term used to refer to individuals of Puerto Rican ancestry who are that are born in New York City.

${ }^{5} \mathrm{OG}$ stands for original gangster or leader of the organization
} 
A leadership position in a street organization can be purchased. Chris described how the gang will give an individual with material wealth a position of power simply to exploit their wealth. This method of acquiring rank is not respected by other members, particularly incarcerated individuals.

[The leader] is going to give you a certain rank to make you feel better about yourself in this gang and all the while, he's going to benefit off of your money situation. You're going to show him how to get money and he's going to give you enough rank to command people as well. So now you have enough rank to do shit you would never dream of. You have money to blow but you have no respect. And a lot of people still won't respect you but they won't go against you because they know who gave you the rank.

While respondents recognize the presence of a hierarchical leadership in both organizational types, they acknowledge that the hierarchy in the street organization changes when a leader is incarcerated. The newly appointed leader can dismantle the existing power structure. Respondents state that this dismantling is common place and results in internal strife within the street organization. Edward described this process as follows:

Let's say the leader of the gang gets sent to prison forever, he's going to think about who he can trust with his gang. Now he's still leader but he no longer is active. He's active in the prison system but not on the street. He needs someone in the street. So he's going to give the 'okay' to this guy. Well this guy just so happens to be cool with you and all your boys... He's gonna make his whole line, a whole new line of captain, lieutenant, sergeant, the general. Everybody's going to be different now... That's when you got inside beef. That's when you got the violence. You see, you got sneaky violence because now that the rank has changed, even though you were [a high rank] you're no longer [that rank] but you got so many people who respect you. So, now you get those people together and you fight the new leader.

Tyrone also discussed internal strife as a result of structural dismantling. He admitted to having a "a group inside of a group" who were prepared for intra-gang violence.

Like if there's something that happens within the [gang]. I'll guarantee these ten people right here aren't going to be the ones that come through looking for me. Instead we gonna be the one to look for somebody else or another group is gonna be looking for this ten.

The notion that leadership within a street gang can change instantly and the presence of internal conflicts suggests that leadership in street gangs differs from prison gangs.

Within prison, there is a hierarchical structure analogous to the street organization, however, the prison gang structure is rigid and not susceptible to power struggles. George states that the leader in prison is respected by all members and his authority is not challenged. Further, when a prison gang leader gives an order, the order is followed without question.

In prison the head of the snake is the head of the snake. Outside, the head of the snake is the leader but he still got people he got to [converse] with. In prison, whoevers the $\mathrm{OG}^{6}$

\footnotetext{
${ }^{6}$ Original Gangster
} 
there, whatever he says goes. OG in jail can be like, 'Yo, everybody we gotta do this and that tonight.' Everybody gotta do it. In the streets, you could run away from things. In prison, you can't.

Because rank is easily awarded in the street gang, street-level rank does not translate into the prison organization. Respondents state that individuals who hold a position in the street organization cannot be compared to individuals who hold the same rank in the prison organization because rank in prison is earned.

I mean, a Foot Solider in prison was not a Foot Solider in the streets... a Foot Solider in the street is a "mamao" compared to one in prison. We had to do a lot in prison and again it involved numerous things that were not part of our culture in the street.

Tyrone confirms this difference in rank and states that individuals in the street organization only attain a higher rank due to the incarceration of the 'true' leader. He states that if the 'true' leader were to be released, the current leader would be demoted.

The difference is the OG in prison is really an OG... Not to take any credit away from the OG on the street. It just to say that he's only the OG because the real OG is in prison and ain't never coming home. If [the OG] was home, the OG on the street will probably be a lieutenant. He wouldn't be an OG.

While street rank is not respected in prisons, rank earned in prison must be respected by all street gang members. Prison rank is viewed as truly earned and therefore warrants respect. Mike explains that a member's unwillingness to respect prison rank can result in discipline if that individual were to be incarcerated.

You take [prison rank] out with you and you don't care what nobody on the street say because even if on the streets you go through hell, when those people go back to prison, they gonna pay for it. Because when you get in prison, [that rank is] worth something. You can get it on the street and still go hard for it but you get stamped at prison, it's worth something. It's like gold.

Lastly, ranks in prison differ based on the expected roles and functions of each rank. Respondents indicate that their responsibilities differ when entering prison. Brandon asserted that his role in the street organization was carrying out "missions" that generally involved committing armed robberies. When he entered prison his role became that of peace keeper. He actively sought out opportunities to quell potential violence. The respondent's statements regarding the rigid nature of prison gang leadership structures and differences between membership requirements are supported by the existing gang literature (See Camp and Camp, 1985). "Compared to street gangs, prison gang members are typically more organized, entrepreneurial, covert, selective, and strict" (Skarbek, 2014, p. 9). The differences across membership, rank, and role are the result of the prison environment. Because members are not free to leave the environment, they are forced to interact with the gang, obey its leaders, and tolerate the punishments meted out by the gang.

\footnotetext{
${ }^{7}$ Mamao is a Puerto Rican slang word that means 'punk' or 'sucker'. The word is derived from the word mamado which means sucked.
} 


\section{Organizational Operations}

One of the major differences between prison and street gangs concerns organizational operations. Because prison gangs are confined to close spaces and there is a rigid leadership structure, prison gangs have strict control over the movements of their members. Clarence, described the morning routine of his prison gang as follows:

Aiight, so you wake up, they bust your door around 7:45 for breakfast. You wake up, you get dressed, grab your knife. Then whatever corner your gang meet in, there's about 6 corners on the tier so at 7:45 you gotta be dressed with your knife. If this is your corner, you gotta be in the corner by 7:45 soon as your door open you gotta be in the corner. [If you're not in the corner] then they discipline you... So once ya'll meet in that corner, ya'll observe the tier, then ya'll go get ya'll food. Then you go back to your table. You got two people standing, probably seven people sitting, however many of ya'll are on the tier, then ya'll rotate. Then you go back to your cells, lock the doors. Then you come out about 8:30 for recreation, go back in the corner, everybody come out then ya'll go to recreation together.

This need for strict regimented behavior is the result of a need for safety. While respondents also spoke of the need for protection in the streets, the dangers in prison were ever-present and required a regulation of members' behaviors.

\section{Rules of Conduct}

In line with the need for safety, was the need to maintain strict rules of conduct in prison. Rules of conduct are outlined in the gang's written manifesto or constitution. In prison, manifestos are distributed to all members of the gang and individuals must live by the rules or face disciplinary actions. In addition to a written copy of the rules, 'shot callers' meet with new or incoming members to discuss the rules (Skarbek, 2014). Obeying the gang's rules of conduct in prison was essential to the safety of the organization and its members. "The only objective which the group and leader share is to make the time pass as agreeably and as comfortably as possible" (Clemmers quoted in Skarbek, 2014, p. 31). Tyrone explains that the need for safety was the primary reason why street behavior was not tolerated in prison.

You see, so when you step into prison, all that 'I'm the man shit' that you was doing on the street, get your ass killed in there... You'll follow the rules in prison or you'll get dealt with just like that. There is no waste of time. [If the leader] says do it, you do it.

Due to the heightened need for safety in prisons, members were required to travel in numbers. This requirement made what would be simple tasks in the streets, difficult to accomplish in prison. Tony described the difficulty associated with obtaining a doctor's appointment in prison.

If I gotta go to the doctor, you and two other people gotta drop doctor slips with me, just to go to the doctor. If I'm on the list by myself, I ain't going unless there's two or three of my [brothers] going with me. 
The need for strict adherence to the rules is the result of living within an environment where one can be attacked at any moment, an environment where one is unable to flee impending danger. Inmates are limited in their ability to move within the correctional facility, both by formal and informal institutional level policies (Skarbek, 2014).

\section{Conflict Management}

The adherence to rules also affected how the organizations managed conflict within their respective environments. Respondents described violence in prison as organized and controlled because of a mutual need for violence reduction. On the streets, individuals felt they were free to attack anyone as long as they were not a member of their organization. In prison, members must obtain authorization for all violence from a high-ranking member of their organization. "Gangs must authorize the use of violence because spontaneous unplanned violence causes problems for other inmates" (Skarbek, 2014, p. 86). Morgan explained the difference in violence across street and prison organizations.

On the streets, I was wild. I could do anything to anybody, as long as they wasn't a King. When I got locked up, it was way different. I had to ask for permission. Even if a dude said some slick shit to me, I had to ask for permission to retaliate because anything I did could [affect] everyone in my tier. A lot of the time I ain't get [permission] so I had to eat the disrespect. On the streets, I would have hit dude without a problem.

Morgan's comment suggest that prison gangs act as a barrier to the use of violence to obtain respect that is mandated by the code of the streets (Anderson, 1999).

The difference in conflict management is due to inmate's mutual need to reduce violence in order to avoid losing the "luxuries" they are afforded in prison. Maurice described an incident where members of rival prison gangs developed a truce in order to avoid a lockdown ${ }^{8}$ of the prison.

[The gangs] got tired of getting everything taken from them. Every time they turn around, everything getting taken. TVs getting taken. Microwaves getting taken. Everything ... get taken so they was like "everybody calm down [and] we get it back then". So I look at it like now they got structure now. Everybody not trying to be on the same stuff [as the streets].

"Goods and services can ameliorate the pains of imprisonment, but their availability depends on the effectiveness of extralegal governance institutions" (Skarbek, 2014, p. 7). Trammell (2009) found that gang leaders would discipline any of their members who accrued drug debts or utilized unsanctioned physical violence against rival gangs. This type of behavior could result in a lockdown of the facility that would be detrimental to all inmates. The control over violence exerted by prison gangs does not indicate that violence does not exist within correctional facilities but rather that violence is strictly regulated by gang leaders. Prison gangs will attempt to resolve issues without violence by utilizing 'peacemakers' or 'shot callers'. The environmental restraints of prison require that violence is coordinated to minimize or eliminate negative repercussions.

\footnotetext{
${ }^{8}$ Lockdown refers to a period when all inmates are confined to their cells and are not allowed privileges such as visitation and recreation.
} 


\section{Relationship with Criminal Justice Representatives}

The final major difference between prison and street gangs is their relationships with criminal justice representatives. The street gangs experience a purely antagonistic relationship with law enforcement while prison gangs experience a complicated relationship with correctional officers. The relationship between street gangs and the police involved harassment at the hands of the police that resulted in animosity between the two groups. Police utilized unethical methods to address the street gang problem. The relationship between prison gangs and correctional officers was dependent on the type of correctional officer present. Respondents identified three types of correctional officers with varying relationships with prison gangs.

\section{Police and Street Gangs}

Respondents described how police officers held negative opinions of gang members regardless of how the gang member behaved. Luis described how the stereotypes led police to take aggressive and hostile positions toward the gang members.

So they treat us like we scum basically. Like that's all y'all know is trouble. So we gonna come aggressive at you every single time. And if we could do anything to get y'all off this block or this neighborhood, we will.

The hostility exhibited by the police extended to anyone who resided in the neighborhood, not just gang members. The police made generalizations based on where an individual resided and the clothing they wore. One respondent described how the color of one's clothing affected how police responded to an individual.

Police see you, you got on red, you got on any color, red, purple, blue, they automatically think you part of a gang just because of the area you're in. My area is populated mostly by Bloods so [if the police] see you wearing red on, they just automatically think you're a Blood... They automatically think you selling drugs [or] got a gun on you. And my area's like, right by the precinct. So we got to deal with it all day.

Police officers also would use an individual's gang association to their benefit. George described an incident where police were angered by their inability to find a justification to arrest him and decided to leave George in rival gang territory.

I was in my hood one time. Cops just snatched me up and dropped me off in a place where I'm not supposed to be at... We was in a group, [the police arrived] and everybody ran. So I ran too. I got caught but I had no drugs. So since they knew I ran and I had no drugs, that was their pay back, dropping me off somewhere where they know something's gonna happen to me.

Similar behaviors by police have been documented in Los Angeles (Lait \& Glover, 2002) and Chicago (Edwards, 2011). The murders of several gang members have been linked to this unethical police practice (See Lait \& Glover, 2003; Bentham, 2014 for examples).

Respondents also described how their gang membership results in unjustified punishments including tickets and arrests. 
[The police] treat [gang members] bad. It got to the point like they'll find something and put it on you. Like it may not be yours, but if they find something near you they're going to put it on you... They put a gun on me the first time I got locked up. They picked me because, I was in a gang [and] I was known in that city. Anything that came up in that area they came after me... It got to the point my mother had to go to internal affairs on them, because they would roll up and [search] me or my little sister, and she ain't even in a gang. [The police] just ain't like me... So, I got locked up and [the police] came to visit me and told me "Tell us who [name redacted] is or we gonna make you go away for a long time."

Law enforcement also actively attempt to dismantle the organizations by targeting the leaders. This law enforcement tactic included wrongfully arresting gang members by planting evidence on them and threatening the individuals with lengthy prison sentences if they did not provide the police with information about a high ranking gang member. Richard described one such incident.

[The police] pick and choose who they want to mess with because it's not too many members who have a lot of [rank]. [There are] a lot of big homies down in prison who are doing a lot of time. [The police] can't go there and say [the incarcerated members] did it. So they going to the next one [in the hierarchy]. It's like, if you can't get the big fish, go for the little one to get the big fish. So they tryna pick at every little thing so they can arrest someone for something. (Maurice)

The relationship between gang members and police was further strained because police departments were unwilling to assist gang members with issues within the neighborhood. David described how his organization attempted to address issues in their neighborhood by speaking with the police, however, the police ignored their calls for action.

I mean, there was bad blood between cops and the Nation. I remember us going to the precinct and bringing up certain issues that we had in the neighborhood like prostitution, crack houses, stuff like that but nothing would ever get done. So, I mean, I would say that's one of the reasons why we really had bad blood with the cops and we just took it upon ourselves to fix what they were supposed to be fixing.

This antagonistic relationship between street gangs and law enforcement was echoed by all thirty respondents. Each provided stories of abuse, violence, and harassment at the hands of the police. The same is not true of the relationship between prison gangs and correctional officers.

\section{Correctional Officers and Prison Gang Members}

Correctional officers and prison gang members have a relationship best described as complicated. Whether the relationship is antagonistic or beneficial is dependent on the type of correctional officer present within the facility. Several respondents described various types of correctional officers including the greasy officer, the gang affiliated officer, and the sadistic officer.

The greasy correctional officer is corrupt, actively engages in the prison black market and allows gang members to control the prison units. Johnny described how greasy officers supplement their income through the black market. 
[There are] greasy-ass officers who if you do something for them, they'll do something for you. You've got your officers who bring their work here... CO's bring in phones, let drugs in.... They getting paid off of it. They getting paid top dollar. The money is in the prison. There is no one on the street making money like someone in the prison is making money.

Greasy officers also use gang members to maintain order within a prison unit. Clarence described how correctional officers would chose known gang leaders and make them responsible for ensuring the prison unit was properly maintained. The gang leaders were authorized to use violence to maintain order.

So, on a tier you got 80 people in one tier... about 75 will be gang banging. Then you got [correctional officers] that can't control everybody so they'll pick out the two gang leaders, make them tier reps. They tell the tier rep, I want these people locked up, I want the chow area cleaned, I want this that and the third done. So, the gang members will do that just for maybe a sandwich or a soda or just to let them stay out on the unit a little longer... If its people acting up on this tier, the $\mathrm{CO}$ will go somewhere and get the gang member leader, bring 'em back, "Yo, you gotta handle him. Beat him up" and the gang member will beat him up.

The relationship between greasy officers and prison gang members is mutually beneficial and stands in stark contrast to the relationship between police officers and street gang members. Greasy officers are willing to work within the gang structure rather than attempting to dismantle the structure. This relationship counters the official criminal justice narrative which suggests that prison gangs are problematic entities. The 'greasy' officer typology is supported by literature that suggests correctional officers utilize gang members to control the facilities and are actively involved in corruption (Hunt et al, 1993; Camp and Camp, 1985; McCarthy, 1996).

The second type of correctional officer identified by respondents were the gang affiliated correctional officers. These officers were street gang members who became educated and secured careers. Brandon described how some street gang members adhered to the positive influences within the gang and achieved success.

Some of the correctional officers [are] gang bangin' themselves. Like, everybody didn't get locked up, some people stayed on that path, some people had mature figures in the gang that made sure you went to school, made sure you went in the house at a correct time.

Although the gang affiliated correctional officers had achieved some level of success outside of the gang, they were obligated to support the prison gang. This obligation included trafficking contraband and ensuring that the gang did not receive punishment for misbehavior. Reggie described an incident where six members of the Almighty Latin King and Queen Nation (ALKQN) assaulted an inmate. The correctional officer on duty was a member of the ALKQN. The officer identified Reggie and five members of the United Blood Nation as the assailants.

The [correctional officer] that picked me out of the Latin King fight, that I had nothing to do with, he was Latin King. So I figured he picked me and five [blood members] out to keep his brothers on the pod. That's the way I felt. Because [the prison] got cameras so you know who jumped on this man but you still got me doing some 225 days in [solitary confinement] for something I didn't even do. 
The gang affiliated correctional officer also stands in stark contrast to street level law enforcement because the gang affiliated correctional officer has a positive relationship with the inmates who belong to his organization. The gang affiliated typology is supported by a recent Department of Investigations report that revealed correctional officers on Riker's Island were gang affiliated (Schwirtz \& Winerip, 2015).

The final type of correctional officer identified by respondents, the sadistic officer, has a relationship that is analogous to the relationship between law enforcement and street gang members. These correctional officers hold negative perceptions of inmates and utilize violence against inmates. Tyrone described how sadistic correctional officers would destroy an individual's property simply because he does not fear repercussions.

You got your asshole officer who come through and while you're in the yard, he'll come through and rip open every piece of food that you have. [He'll] dump it on your bed, the floor... He thinks he can do what he wants to you.

These officers also utilize an individual's gang affiliation against them. Clarence described how officers would pit rival gang members against each other merely for sport.

So, if I'm Blood and you Crip, the officer will put you in my room knowing I got a big knife in there. And they'll stand at the door and bet on who's [going to] win.

Correctional officers also utilized rival gang members to dole out punishment for assaults against correctional officers. Tyrone described an incident where a correctional officer retaliated against him for ordering another gang member to throw urine at the officer.

My door gets bust and I'm wondering why because I already came out today... We go to the door. They let in about 24 cells of Crips there. That's 48 people. I'm Blood. They Crip. It's war. But that CO popped my door on purpose. That was payback time.

The sadistic correctional officers align with the police officers described by respondents. This typology is supported by the vast body of literature on correctional officer use of violence (Bowker, 1980; Cohen, Cole, \& Bailey, 1976; Hemmens \& Atherton, 2000; Hemmens \& Stohr, 2001). This typology illustrates the complicated relationship between correctional officers and prison gang members that does not exist between police officers and street gang members.

The complex nature of the correctional officer and inmate relationship maybe the result of environmental factors. Because officers are dependent on inmates to minimize violence within the institution, officers may adapt by developing relationships with are beneficial to them.

\section{Discussion and Conclusion}

Environmental differences affect many aspects of gangs. Although the initiation processes and membership requirements were constant across both environments, membership within the prison organization was less fluid than the street organization. Prison gang members often did not recognize street gang membership as legitimate. Unlike their street counterparts, prison gang members were unable to reduce their level of gang activity due to living in a constrained and controlled environment. Leadership structures were also more fluid within the street gang than in 
the prison gang. Within the street organization, leadership could be purchased and one individual could dismantle the entire existing leadership structure. The prison gang structure was rigid and not susceptible to power struggles because of the controlled environment. Being housed with fellow gang members opened individuals up to immediate victimization if they challenged the power structure. Unlike with street gangs, prison gang members cannot merely relocate to avoid interactions with the gang. The gangs have developed methods of communication that ensure any member who attempts to leave the organization will suffer in every unit or facility.

Within prisons, however, the need for safety is intensified by the reality that inmates are housed in small units and are easily susceptible to attacks. The ease by which prison gang members may fall victim to attack results in major differences between the organizational operations of prison and street gangs. Prison gang members must maintain strict daily routines, which dictate their every movement. Within prisons, gang members must obey these rules of conduct or face violent disciplinary action from their organization. By contrast, street gang members are free to roam their neighborhoods often with little fear of reprisal. Prison and street gangs also differ with regard to conflict management. Prison gang members must acquire permission to attack or retaliate against another inmate, even inmates from rival gangs. This requirement is due to a mutual need to reduce the level of violence within the prison. Any form of violence committed by one inmate may result in the loss of privileges for both his organization and all inmates within the facility. Within street gangs, members are free to attack anyone who is not a member of their own organization.

The last major difference between prison and street gangs is their relationships with authority. Respondents described their relationship with police as antagonistic. Police officers dehumanized gang members, inflicted violence against the individuals, and actively attempted to dismantle their organizations. The relationship between correctional officers and prison gang members is complex and complicated. Respondents identified a typology of correctional officers that explained the relationship. The typology consisted of three types of officers: greasy, gang affiliated, and sadistic. Greasy officers were corrupt and often used gang members to control other prisoners. Gang affiliated officers were gang members who were able to earn positions as correctional officers. These officers were loyal to their organizations and protected their organizations. Sadistic officers were analogous to street-level law enforcement. These officers held negative views of inmates and used their authority to abuse inmates.

The findings have implications for existing correctional policies. Respondents indicated that although they were convicted of non-violent crimes, they were housed in maximum security facilities due to their street gang affiliation however, their street gang membership was not recognized by the prison gang. Existing classification policies are problematic because they assume that street gang membership will result in violent behavior while incarcerated. "Studies provide no clear empirical link between gang membership and prison violence" (Skarbek, 2014, p. 98). Studies have found, however, that the individuals who are most likely to commit violent acts in prison are non-violent offenders housed with violent offenders (California Department of Corrections, 1975). Transfer request policies within correctional facilities are also flawed. Respondents expressed correctional officers' unwillingness to transfer individuals out of housing units even when their physical safety was in jeopardy. Because correctional officers have established relationships with gang leaders, the officers ignore cries for help from inmates who have been misclassified or those victimized by gangs. Respondents illustrate how gang members are unable to safely transfer out of units even after being sexually and physically victimized. These 
findings suggest that the current transfer policies are inadequate. Informal governance structures trump the formal governance structures. Lastly, the findings suggest a need to re-evaluate correctional officer hiring processes. Within the past two years, correctional officers have been investigated, arrested, or indicted for smuggling narcotics (Schwartz \& Wineripe, 2015), raping inmates (Lafer, 2014; Marimow \& Wagner, 2013), and murder (Walsh, 2014). The actions of correctional officers described in this study and the recent revelations regarding correctional officer behavior nationwide suggest that the current hiring practices are flawed.

The present study contributes to the existing gang literature by highlighting the differences between prison and street gangs. The differences outlined in this paper suggest that gang researchers must abandon the notion that prison and street gangs are synonymous entities. While prison and street gangs do serve similar functions (e.g. financial support), the data suggests that they differ across several characteristics including membership, leadership, and ideologies. The differences identified reveal a need to reevaluate and reassess theoretical frameworks and policies aimed are addressing gang violence. This paper should serve as a starting point for analyzing the two organizations as distinct entities each affected by their respective environments.

\section{Disclosure statement}

No potential conflict of interest was reported by the authors.

\section{References}

Beaumont de, G., \& Tocqueville, A. (1833). On the penitentiary system in the United States and its applications in France. Philadelphia: Carey, Lea, and Blanchard

Bentham, M. (2014). Scotland Yard officers dump gang members on rivals turf after questioning them. London Evening Standard. Retrieved from www.standard.co.uk/news/crime/scotland-yard-officers-dump-gang-members-on-rivalsturf-after-questioning-them-9599785.html.

Bernard, H.R. \& Ryan, G.W. (2009). Analyzing qualitative data: Systemic approaches. Thousand Oaks CA: Sage Publications.

Bowker, L. H. (1980). Prison victimization. New York, NY: Elsevier Science.

Brotherton, D. \& Barrios, L. (2004). The almighty Latin King and queen nation: Street Politics and the transformation of a New York City street gang. New York, NY: Columbia University Press.

Brotherton, D. \& Barrios, L. (2011). Banished to the homeland: Dominican deportees and their stories of exile. New York, NY: Columbia University Press.

Camp, G.M. \& Camp, C. G. (1985). Prison gangs: Their extent, nature, and impact on prisons. Washington, D.C.: U.S. Government Printing Office.

Clemmers, D. (1940). The prison community. New York, NY: Holt.

Cohen, A., Cole, G., \& Bailey, R.G. (1976). Prison Violence. Lexington, MA: Lexington Books.

Cohen, S. \& Taylor, L. (1972). Psychological survival: The experience of long-term imprisonment. Harmondsworth: Penguin. 
Damgacı, F. K., \& Aydın, H. (2013). Türkiye'deki Eğitim Fakültelerinde Görev Yapan Akademisyenlerin Çokkültürlü Eğitime İlişkin Görüşleri. Dicle Üniversitesi Ziya Gökalp Eğitim Fakültesi Dergisi, 21(2), 314-331.

Decker, S.H., Bynum, T.S., \& Weisel, D.L. (1998). Gangs as organized crime groups: A tale of two cities. Justice Quarterly, 15 (2), 395-423.

Deniz, M., \& Ersoy, E. (2016). Examining the Relationship of Social Skills, Problem Solving and Bullying in Adolescents. International Online Journal of Educational Sciences, 8(1), 1 -7.

Diego Vigil, J (2002). A rainbow of gangs: Street cultures in the mega city. Austin, Texas: University of Texas Press.

Edward, S. (2011, March). Video: Questionable police actions caught on tape. WBEZ 91.5: City Room. Retrieved from http://www.wbez.org/blog/city-room-blog/2011-03-22/videoquestionable-police-tactics-caught-tape-84086.

Erikkson, P., Henttonen, E., \& Merilainen, S. (2012). Ethnographic field notes and reflexivity. Pp. 9-22 in Loshini Naidoo (Ed.). An ethnography of global landscapes and corridors. Rijeka, Croatia: InTech.

Esbensen, F., Winfree, L.T., He, N., Taylor, T.J. (2001). Youth gangs and definitional issues: When is a gang a gang, and why does it matter? Crime \& Delinquency, 47 (1), 105-130.

Faugier, J. \& Sargeant, M. (1997). Sampling hard to reach populations. Journal of Advance Nursing, 26 (4), 790-797.

Fleisher, M.S., \& Decker, S.H. (2001). An overview of the challenge of prison gangs. Corrections Management Quarterly, 5 (1), 1-9.

Fortune, S.H. (2003). Inmate and prison gang leadership. Ann Arbor, MI: ProQuest.

Gaes, G.G., Wallace, S., Gilman, E., Klein-Saffran, J., \& Suppa, S. (2001). The influence of prison gang affiliation on violence and other prison misconduct. The Prison Journal, 82 (3): 359385.

Goffman, E. (1961). Asylums: Essays on the social situation of mental patients and other inmates. New York, NY: Anchor Books.

Guest, G. (2012). Applied thematic analysis. Thousand Oaks, California: Sage.

Hemmens, C., \& Atherton, E. (2000). Use of force: Current practice and policy. Lanham, MD: American Correctional Association.

Hemmens, C., \& Stohr, M. K. (2001). Correctional staff attitudes regarding the use of force in corrections. Corrections Management Quarterly, 5, 26-39.

Hunt, G., Riegel, S., Morales, T., \& Waldorf, D. (1993). Changes in prison culture: Prison gangs and the case of the "Pepsi generation". Social Problems, 40 (3), 398-409.

Irwin, J. (1980). Prisons in turmoil. Boston, MA: Little Brown.

Jacobs, J.B. (1977). Statesville: The penitentiary in mass society. Chicago: University of Chicago Press.

Kaya, I. \& Aydin, H. (2014). Pluralism, Multiculturalism and Bilingual Education [Çoğulculuk, Çokkültürlü ve İkidilli Eğitim]. Ankara: Ani Press.

Lafer, S. (2014). Democratic Design for the Humanization of Education. Journal of Ethnic and Cultural Studies, 1(1), 6-12.

Lait, M. \& Glover, S. (2003, March ). Two officers are sued over teen slaying. Los Angeles Times. Retrieved from http://articles.latimes.com/2003/mar/11/local/me-vega11

Low, S.M. \& Lawrence-Zuniga, D. (2003). The anthropology of space and place: Locating culture. Malden, MA: Blackwell Publishing. 
Marimow, A. \& Wagner, J. (2013, April). 13 correctional officers indicted in Maryland, accused of aiding gang's drug scheme. Washington Post. Retrieved from https://www.washingtonpost.com/local/thirteen-correctional-officers-indicted-inmaryland/2013/04/23/6d2cbc14-ac23-11e2-a8b92a63d75b5459_story.html?noredirect=on\&utm_term=.b59679a0b6af.

Maxwell, J.A. \& Miller, B.A. (2007). Categorizing and connecting strategies in qualitative data analysis. In P. Hesse-Biber (Ed.) Emergent Research Methods, Thousand Oaks, CA; Sage Publications.

McCarthy, B. J., Jr. (1996). Keeping and eye on the keeper: Prison corruption and its control. In M. C. Braswell, B. R. McCarthy, \& B. J. McCarthy (Eds.), Justice, crime and ethics (2nd ed., pp. 229-241). Cincinnati, OH: Anderson.

Michou, A., Mouratidis, A., Ersoy, E., \& Uğur, H. (2016). Social achievement goals, needs satisfaction, and coping among adolescents. Personality and Individual Differences, 99, 260-265.

Parenti, C. (1999). Lockdown America: Police and prisons in the age of crisis. New York, NY: Verso.

Rhodes, L.A. (2001). Toward an anthropology of prisons. Annual Review of Anthropology, 30: 6583.

Rodgers, D. \& Jensen, S. (2008). Revolutionaries, barbarians or war machines? Gangs in Nicaragua and South Africa. Socialist Register, 45: 220-238.

Saldana, J. (2012). The coding manual for qualitative researchers. Thousand Oaks, CA: Sage Publications.

Schwirtz, M. \& Winerip, M. (January $15^{\text {th }}, 2015$ ). Warning signs overlooked in hiring for New York City jails: Agency report finds criminal histories and gang ties among Rikers officers. New York Times. Retrieved from http://www.nytimes.com/2015/01/15/nyregion/hired-fornew-york-jails-despite-warning-

signs.html?action=click\&contentCollection=Opinion\&module=RelatedCoverage\&region $=$ Marginalia\&pgtype $=$ article

Seidman, I. (2013). Interviewing as qualitative research. New York, NY: Columbia University Teaching College.

Skarbek, D. (2014). The social order of the underworld: How prison gangs govern the American penal system. Oxford: Oxford University Press.

Suliman, M., Shah, M., Ullah, A., \& Jamal, H. (2016). Ethnicity Based Social Exclusion of Nomads in Khyber District Malakand, Pakhtunkhwa-Pakistan. Journal of Ethnic and Cultural Studies, 3(1), 11-19.

Sykes, G. M. (1958). Society of captives. Princeton, NJ: Princeton University Press.

Trammell, R. (2009). Values, rules, and keeping the peace: How men describe order and the inmate code in California prisons. Deviant Behavior, 30 (8), 746-771.

Wang, T. (2015). Marginality of rural migrant students in eleven Chinese high schools. Journal of Ethnic and Cultural Studies, 2(2), 21-32.

Yigit, I. H., \& Tatch, A. (2017). Syrian refugees and Americans: Perceptions, attitudes and insights. American Journal of Qualitative Research, 1(1), 13-31. 
Manuscript received April 03, 2018

Final revision received May 30, 2018

Accepted June 02, 2018

Jennifer M. Ortiz is an assistant professor of criminology and criminal justice at Indiana University Southeast. She holds a doctorate in criminal justice from John Jay College of Criminal Justice.E-mail: imortiz@ius.edu 